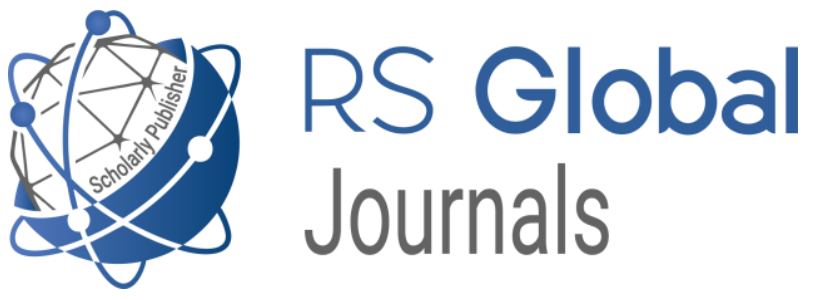

Scholarly Publisher

RS Global Sp. z O.O.

ISNI: 0000000484952390

Dolna 17, Warsaw, Poland 00-773

Tel: +48226022703

Email: editorial_office@rsglobal.pl

JOURNAL International Journal of Innovative Technologies in Social Science

p-ISSN

2544-9338

e-ISSN

2544-9435

PUBLISHER

RS Global Sp. z O.O., Poland

ARTICLE TITLE $\quad$ PAR. 2 OF THE ADMINISTRATIVE VIOLATIONS AND

THE ADMINISTRATIVE LIABILITY UNDER ART. 24, SANCTIONS ACT

$\operatorname{AUTHOR}(\mathbf{S})$

Plamen Rusev

Plamen Rusev. (2021) The Administrative Liability Under Art.

ARTICLE INFO 24, Par. 2 of the Administrative Violations and Sanctions Act. International Journal of Innovative Technologies in Social Science. 3(31). doi: 10.31435/rsglobal_ijitss/30092021/7642

DOI https://doi.org/10.31435/rsglobal_ijitss/30092021/7642

RECEIVED

25 May 2021

ACCEPTED

19 July 2021

PUBLISHED

24 July 2021

LICENSE

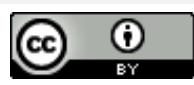

This work is licensed under a Creative Commons Attribution

4.0 International License.

(C) The author(s) 2021. This publication is an open access article. 


\title{
THE ADMINISTRATIVE LIABILITY UNDER ART. 24, PAR. 2 OF THE ADMINISTRATIVE VIOLATIONS AND SANCTIONS ACT
}

\author{
Plamen Rusev, Department of Public and Legal Sciences Faculty of Law and History, South-West \\ University "Neofit Rilski", Blagoevgrad, Bulgaria
}

DOI: https://doi.org/10.31435/rsglobal_ijitss/30092021/7642

\section{ARTICLE INFO}

Received 25 May 2021

Accepted 19 July 2021

Published 24 July 2021

\section{KEYWORDS}

manager, instigation, admission, administrative responsibility.

\begin{abstract}
The article examines the administrative penal liability of employees and managers of enterprises, institutions and organizations under article 24, par. 2 of Administrative Violations and Sanctions Act (AVSA). The general character of the responsibility and the relation between the institutes of the criminal and administrative law in connection with the application of art. 24, par. 2 of the law are discussed. The paper analyzes the preconditions of the responsibility under art. 24, par. 2, as well as admission and abetment as forms of responsibility of the heads of enterprises, institutions and organizations. It is concluded that the setting of additional requirements to the responsibility of the heads of organizations, as well as its direct connection with the guilty administrative violation by the respective employee, complicates the implementation of the administrative penalty and withdraws the administrative bodies from the application of article 24, par. 2 of the Administrative Violations and Sanctions Act.
\end{abstract}

Citation: Plamen Rusev. (2021) The Administrative Liability Under Art. 24, Par. 2 of the Administrative Violations and Sanctions Act. International Journal of Innovative Technologies in Social Science. 3(31). doi: 10.31435/rsglobal_ijitss/30092021/7642

Copyright: (C) 2021 Plamen Rusev. This is an open-access article distributed under the terms of the Creative Commons Attribution License (CC BY). The use, distribution or reproduction in other forums is permitted, provided the original author(s) or licensor are credited and that the original publication in this journal is cited, in accordance with accepted academic practice. No use, distribution or reproduction is permitted which does not comply with these terms.

Introduction. According to the Bulgarian legislation the administrative penal liability is personal. This is explicitly stated in Art. 24, par. 1 of the Administrative Violations and Sanctions Act (AVSA). The personal character of the administrative penal liability means that it could be directed only towards the person who perpetrated the violation ${ }^{1}$. On the other hand, it also means that the administrative liability could be imposed only on individuals - natural persons. Hence, the imposition of an administrative penalty on collective entities, such as juridical persons or organizations without legal personhood, is inadmissible. There is an exception of this rule, provided in Art. 83 of AVSA, according to which a property sanction can be imposed on the juridical persons for non-fulfillment of obligations to the state or the municipalities, when this is provided by a particular legal act or decree. This liability of the juridical persons is autonomous, the property sanctions could be imposed independently from the administrative penalties of the natural persons - perpetrators of the violation. There is another exception of the principle, according to which the legal liability is personal in nature, stipulated in the State and Municipalities Resposibility for Damage Act (SMRDA) ${ }^{2}$. This normative act provides a liability of the state and public bodies for damages suffered by private persons as a result of unlawful acts, actions and omissions by civil servants, committed in the course of or in the connection with the performance of their duties. In those cases the damages are not caused directly by the subject against whom the claims

\footnotetext{
${ }^{1}$ Boichev, G. The Legal Liability. S.: Iurispres, 2003, p. 162.

${ }^{2}$ Buchkova, V. Claim Proceedings for damages from illegal administrative activity. S.: BAS, 2020, p. 179.
} 
are made ${ }^{1}$. Although nowadays the most legal acts, that regulate various administrative regimes, provide administrative liability of juridical persons, initially this liability was rare and exceptional ${ }^{2}$.

Violations in the field of administrative law are made not only in connection with the activities of juridical persons. Such are also committed in connection with the activities of various nonpersonified organizations. However, their liability is not enshrined in the law and this is a reason for the number of controversial issues in the court practice. At the same time, the AVSA stipulates that employees who have committed administrative violations, as well as the managers who have ordered or allowed them to be committed, are liable for administrative violations committed during the activities of institutions, enterprises and organizations. Since the liability under Art. 24, par. 2 AVSA is provided specifically for the activities of these associations, it can be concluded that the legislator had in mind those enterprises, institutions and organizations that are not legal entities within the meaning of the law.

\section{Methodology.}

The systematic, analytical and comparative research method are used in the article. The systematic and analytical method reveals the relationship between existing legal institutes and the specific consequences of their differences, and the comparative method examines the relationship between the administrative liability and penal sanctions.

\section{The Administrative Liability under Art. 24, par. 2 AVSA}

In the field of administrative penal law, juridical persons are sanctioned as an exception, and the punishment of organizations, which haven't got legal personhood, granted by the law, is impossible as a rule. On the other hand, various types of violations are often committed by associations, and other entities, to whom the law does not confer the status of a "legal person". This raises the question of the mechanisms for achieving the prevention of these offenses. Precisely for that, the legislator has provided for some special rules in the AVSA in connection with the administrative violations committed during the carrying out the activity of enterprises, institutions and organizations. The various forms of associations of many natural or collective individuals with the purpose of achieving common goals are important for society. Today those entities are of paramount importance for public, economic, political and social life. Therefore, the legislator faces the problem of ensuring legal certainty and the lawful development of the legal relations in which these associations participate in order to achieve the maximum prevention of administrative violations. Administrative liability is one of the tools for achieving it. In the case of violations committed in relation with the activities of various collective entities, the simultaneous impact both on the organization and natural persons - perpetrators of the violation, has significant potential to achieve the preventive effect. That is why the legislator has introduced legal mechanisms through which to sanction the persons, part of an association, in connection with which the administrative violation has been committed. One of these mechanisms is established in Art. 24, par. 2 AVSA against the employees and managers who have ordered or allowed the commission of an administrative violation. The rule of Art. 24, par. 2 AVSA is related to the principled impossibility for imposing an administrative penalty on the association itself, defined as an institution, enterprise or organization in the law.

In the theory, different opinions are expressed regarding the nature of the liability of the subjects under Art. 24, par. 2 AVSA and whether it constitutes an exception to the principle of the personal liability. According to Prof. Ts. Sivkov, the norm of Art. 24, par. 2 AVSA establishes an exception to personal administrative liability. ${ }^{3}$ The same opinion seems to be shared by I. Iliev, who, considered the problem in the context of the rule of personal liability and points out that the natural persons who represent the juridical person are administratively liable for the unlawful acts committed by this juridical person. ${ }^{4}$ On the other hand, there is the opinion of Prof. K. Lazarov, according to whom: "... here too the liability is based on personal guilt and on an act of the responsible person, expressed in the immediate commission of the violation or in an order or culpable admission of the

\footnotetext{
${ }^{1}$ Buchkova, V. The Parties Concerned under the Administrative Procedure Code. S.: Sibi, 2015, p. 112.

${ }^{2}$ Saharov, K. Analysis of Changes and Amendments in Legal Regulations concerning Admin-istrative Penalty of Legal Persons and Merchants-Natural Persons. - Pravna Misal, 2007.

${ }^{3}$ Sivkov, T. The Administrative Penalty. Substantive and Procedural Issues. S.: Sofi-R, 1998, p. $23-25$.

${ }^{4}$ Iliev, I. Administrative Law. S.: Publishing House "Zhazhda" 1995, p. 118.
} 


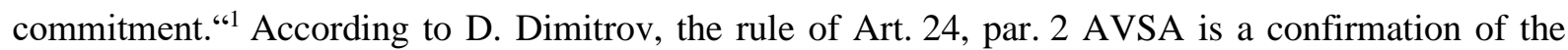
principle of personal liability ${ }^{2}$. According to S. Stoev this norm further develops the principle of personal liability. ${ }^{3}$ Those opinions impose the conclusion that there are two essentially different views on the nature of the liability under Art. 24, par. 2 AVSA. I think that the right opinion is that the rule of Art. 24, par. 2 AVSA confirms the principle of personal administrative liability and further develops it by connecting the administrative liability with the activity of the legal entity.

The liability under Art. 24, par. 2 AVSA is an administrative liability of a natural person who is in a certain legal relationship with the organization, institution or enterprise, in which activity the administrative violation has been committed and they occupy a certain position in the hierarchical "corporate" structure. From this point of view, subjects of liability under Art. 24, par. 2 AVSA are two groups of persons - employees and managers.

The workers and employees who are liable under Art. 24, par. 2 AVSA are natural persons who can be employed in private or public organization with or without legal personhood. The employment may have been arisen on the base of Labour Code or Civil Servants Act, as a civil-service relationship between the State and the natural person - civil servant. The natural persons - perpetrators of violation, who have been assigned with work under a civil contract or have carried out the activity on gesture or other reason outside the Labour Code or Civil Servants Act, shall not bear administrative liability under Art. 24, par. 2 AVSA. In these cases, the natural person - a direct offender, does not have the quality of an employee or civil servant. However, they will be able to bear administrative penal liability on a general basis if their act constitutes an administrative violation.

Along with the employees, the managers who have ordered or allowed the commission of a administrative violation in the enterprise, institution or organization, are also responsible for the committed violation. The legal relationship between the managers and the institution, organization or enterprise may have arisen on different grounds from an employment contract or an appointment order. Their activity in connection with the management of the designated structure may arise, for example, by virtue of a management contract or a multilateral legal transaction between partners in a civil partnership. In case the managers are in labor or official legal relations with the institution, enterprise or organization, they may be liable in a personal capacity as employees if they commit an administrative violation in connection with their work or official activity through their own actions.

The liability, provided by art. 24, par. 2 AVSA, always requires the presence of an administrative violation committed by an employee of the enterprise, organization or institution. Whether the employee acted culpably, recklessly or behaved innocently is relevant to the question, who will bear administrative liability. The guilt is related both to the occurrence of the liability of the employees and to the occurrence liability of their managers. Where the employee has acted with negligence or recklessness, no liability arises for either the direct perpetrator of the administrative violation nor the manager, except in cases when the latter acts as an indirect perpetrator. In addition, the liability of the manager is conditioned by a proven administrative violation done by an employee under their control. As adopted in one court decision of the Administrative court - Sofia City: “... the chief of the enterprise may be sanctioned for violations committed by his subordinates, but in this case the responsibility is not objective, and is borne only in case of culpably committed act [of the head of the enterprise] - whether intentional or with negligence." ${ }^{4}$ The liability of the employees under Art. 24, par. 2 AVSA, respectively the liability of their managers, is for personal guilty actions, which are stipulated as an administrative violation by a legal act. That is why the rule of art. 24, par. 2 AVSA is not an exception to the principle of personal responsibility, but confirms it. At the same time, for the workers and employees of the enterprise has been established a circumstance excluding the liability execution of an illegal order (art. 25 AVSA).

\footnotetext{
${ }^{1}$ Lazarov, K. Administrative Law. S.: Feneia, 2009, p. 237-238.

2 Dimitrov, D. Administrative Law. General Part. Eighth edition. S.: Siela. 2006, p. 164

${ }^{3}$ Stoev, S. Scientific and Practical Commentary to the Administrative Violations and Sanctions Act. S .: Nauka i izkustvo, 1975, p. 81

${ }^{4}$ See also court decision №3607/31.05.2018 of the Administrative court - Sofia City, according to which “... the responsibility of the manager under Art. 24, par. 1 of AVSA is for personal guilty conduct, expressed in an order or admission of the commission of the violation by another person, but not in its direct commission. In this case, there are no allegations at all of an administrative violation committed by a specific employee, for which the chief of the clinic is responsible as a person - a manager who allowed it to be committed by inaction."
} 
The administrative liability of the managers of the enterprise, institution or organization on the other hand arises when there is an administrative violation that they have ordered or permitted. The order is related to active behavior - a command, brought to the attention of the employees. That is why it is necessary for the direct perpetrator of the violation to act as an employee or as a civil servant of the enterprise, institution or organization. Only then the natural person - direct perpetrator is subject to the disciplinary authority of the manager and should comply with manager's orders and only then the manager will have the opportunity to control the actions of the direct perpetrator of the administrative violation. The order must be given culpably, but the norm does not require a certain form of guilt. Therefore, the order for committing the administrative violation may have been made intentionally as the manager was aware of the public danger of the act and intended or agreed to the occurrence of its illegal consequences, or by negligence - as he was obliged and able to foresee the consequences of the violation. When ordering, the manager is not responsible for another's act. His liability is not an objective one. He is administratively liable for his own conduct. When the manager intentionally orders the employee to commit an administrative offense, they will be abettor or indirect perpetrator.

The abetment to commit an administrative violation is in principle not punished in accordance with Art. 10 AVSA. According to the cited provision, it is punishable only in the cases provided for in the respective act or decree. AVSA lacks a definition of abettor. But a definition of abettor to a crime is given in Art. 20, par. 3 of the Penal Code, which states that: "The abettor is the one who has deliberately persuaded somebody else to commit the crime." The abettor is an accomplice in the commission of the crime. The abetment consists of the intentional mental influence of one person over another in order to make the final decision to commit the specific crime. The mental impact can take place in a variety of ways, including by giving orders that the incited should follow. The incited also acts intentionally in committing the crime. Applied on the field of administrative punishment, the manager is the instigator, because it is he who orders the employee to commit the administrative violation.

The manager will be an indirect perpetrator of the administrative violation, when he has deliberately ordered the commission of the violation by an employee, when the latter acts innocently or negligently. The concept of the indirect perpetrator is subject of criminal law science. There is an indirect perpetrator when one person uses another person to commit a crime. The person used is criminally irresponsible, either because he acts innocently or because he acts negligently ${ }^{1}$. In the area of administrative punishment, indirect perpetration will occur when one person uses another to commit an administrative violation. In this case, the manager uses the employee for the purpose of committing the administrative violation, and the latter will not be liable because he acts innocently or will be released from liability under Art. 25 AVSA. In these cases, the manager of the enterprise, institution or organization should be liable as a perpetrator of the administrative violation, and not under Art. 24, par. 2 AVSA. It should be noted that in our court practice there is no consensus on the application of the institute of the indirect perpetration. According to some court decisions, "the administrative penal responsibility is personal and, unlike the Penal Code, AVSA does not regulate the so-called indirect perpetration, but only admission under the terms of Art. 24 par. 2 AVSA." 2 According to other court decisions, the administrative violations can also be committed through indirect perpetration. ${ }^{3}$

When the manager ordered the commission of the administrative violation, but did it negligently, he did not foresee the occurrence of the socially dangerous consequences, but was obliged and could have foreseen them or foreseen them, but thought he was going to prevent them. Although it's not a question of abetment or indirect perpetration, the connection between the action of the manager - an order and the implementation of the administrative violation is obvious. If the order had not been given, the negative changes, caused by the act committed by the employee, which constitutes an administrative violation, would not have occurred.

The second case, in which the manager is responsible under Art. 24, par. 2 AVSA is the admission of an administrative violation. The admission is carried out by inaction. There is no obstruction of committing or completing an administrative violation. Admission, like abetment, is in principle not punishable in the field of administrative penal law, as stipulated in Art. 10 AVSA. The admission is not a

\footnotetext{
${ }^{1}$ Stoinov, A. Criminal Law. General part. S.: Siela, 2013, p. 312.

${ }^{2}$ See also court decision from 14.08.2020 rendered by Administrative court - Ruse in administrative criminal case №241/2020.

${ }^{3}$ Court decision № 245/12.11.2015 г. of Administrative court - Shumen.
} 
form of complicity in commission of an administrative violation. It is related to non-exercise or poor exercise of the managerial control functions. The manager intentionally fails to prevent the commission of an administrative violation by an employee or does not prevent the commission of the administrative violation, although he was obliged and could interfere. This is because Art. 24, par. 2 AVSA does not determine the form of guilt in which the manager's admission should be made. However, it should be a culpable act, insofar as the liability under Art. 24, par. 2 is not regulated as objective.

The problem with the application of the legal institutes of admissibility and abetment in the administrative law is disputable, because these acts are punishable only if the respective normative act provides for it (Art. 10 AVSA). In this regard, as provided for the managers, the regulation, established for the various forms of complicity in committing administrative violation under art. 24, par. 2 AVSA is contrary to what is adopted in our criminal law. Thus, the imposition of an administrative penalty for the managers under Art. 24, par. 2 AVSA is related to another condition along with the commission of an administrative violation by the employee. This condition is the stipulation of the possibility to administratively punish the manager for abetment or admission in the specified sense in a respective law or decree. This poses additional obstacles to the engagement of the administrative penal liability of the managers under Art. 24, par. 2 AVSA, which may lead to thwarting their punishment. At the same time, the provision of Art. 24, par. 2 AVSA cannot be applied without interpreting its exact meaning in accordance with the rules of the Law of Normative Acts in connection with the legal concepts used in other normative acts or decrees. ${ }^{1}$ In fact, the legislator often provides for the possibility of punishing the chief of an enterprise, institution or organization for committing violations under a respective normative act. Much less often, however, special laws provide for the imposition of an administrative penalty on managers when they have ordered an administrative violation, i.e. when they acted as abettors. An example of such a normative act is the Forestry Act, which in Art. 269 provides for the imposition of an administrative penalty - a fine, for managers or assignors who have ordered or allowed an administrative violation to be committed under this law and the by-laws on its application.

My opinion is that the provision of Art. 10 AVSA as a legal norm, which excludes the punishment of abetment and admission, inasmuch such liability is provided in a respective law or decree, should not be applied unreservedly and without taking into account the fact that it is not special to the provision of Art. 24, par. 2 AVSA, according to the rules for structure of the normative acts. ${ }^{2}$ Rather, the opposite can be assumed - that Art. 24, par. 2 ZANN provides an exception to the rule that abetment and admission of administrative violations is not punishable except in cases provided by a special law, and this exception applies only to the chiefs of enterprises, organizations and institutions. On the other hand, it is illogical that there are many more provisions in respective legal acts or decrees, stipulating admission as a punishable deed than abetment by order of a manager. Indubitably, a direct order to commit an administrative offense has a higher degree of public danger than the admission of an administrative offense. However, in many cases, there is no logic in punishing admission and not abetment. The provision in respective legal acts or decrees, which stipulate a liability for admission, could be explained with the need for ensuring fair determination and individualization of the administrative sanctions imposed on the manager, who otherwise should be punished with the same administrative penalty provided for the perpetrator. This may explain the fewer provisions, establishing penalties for the chief who ordered the commission of the administrative violation. The manager's behavior in this case is characterized by such a public danger as the behavior of the direct perpetrator of the administrative violation. The legal norm of art. 24, par. 2 aims to ensure the achievement of the individual and general prevention of administrative violations committed during the activities of various collective entities, which often have a hierarchical structure and a complex decision-making system. The administrative offences carried in connection with the activities of institutions, organizations and enterprises are in principle characterized by a higher degree of public danger, insofar as they are committed by natural persons acting within an organized "whole". In this sense, both the abetment and the admission of violations by managers mean either the deliberate commission of offenses to facilitate the achievement of the organizations goals, or an organizational defect. Therefore, in order to carry out general and individual prevention, persons holding control and managerial functions in the organization,

\footnotetext{
${ }^{1}$ Buchkova, V. The Normative Administrative Act. A.: Ekobelan. 2005, p. 138.

${ }^{2}$ As V. Buchkova points out, the norms, which precede the respective provision in the normative act, refer as general to special. Buchkova, The Normative Administrative Act. A.: Ekobelan. 2005.
} 
institution or enterprise should be sanctioned, as they may influence the performance of the activity and eliminate or prevent the possibility of administrative violations in the future. Moreover, as a rule, enterprises, institutions and organizations cannot bear independent administrative penal liability outside the responsibility of their employees, members or managers.

Conclusions. The provision of Art. 24, par. 2 AVSA aims to ensure the preventive effect of the administrative punishment, and not to create a legal opportunity for the guilty natural persons to avoid administrative penal liability. ${ }^{1}$ The institute of art. 24 , par. 2 AVSA is necessary due to the principled impossibility for sanctioning the legal entities such as institutions, enterprises and organizations, and due to the complexity of the hierarchical structure of subordination of those entities. The debates in the law theory and court practice over the many disputable issues around the nature of the institute, provided in Art. 24, par. 2 AVSA, do not contribute to its practical application, but create a basis for divergent views. If Art. 24, par. 2 AVSA is an exception to the principle of personal liability or vice versa, is an important question, as it is related to the assessment of fault. The adoption of one or the other opinion predetermines the nature of the liability under Art. 24, par. 2 AVSA. This liability could be objective if the liable person is responsible for other people's actions. The different opinions on the applicability of the institute of the indirect perpetration in the field of administrative penal law lead in some cases to uncertainty about the grounds for imposing administrative liability on managers for deliberately given, guilty orders, containing an administrative violation, to the employees, placed under their authority. The requirement, according to which the admission and abetment of the violation, must be provided for in a special legal act or decree, leads to contradictory interpretations of Art. 24, par. 2 AVSA in the court practice. The contradictions make the application of the institute of art. 24, par. 2 AVSA difficult and this is one of the reasons for its infrequent use. From this point of view, it is easier for the administrative sanctioning public bodies to not seek to impose the personal liability of the individuals within the organization, especially when there is an opportunity for imposing a property sanction on the institution, enterprise or organization with legal personhood, provided by law. Moreover, the liability of legal persons does not require proof of guilt.

\section{REFERENCES}

1. Boichev, G. The Legal Liability. S.: Iurispres, 2003.

2. Buchkova, V. The Parties Concerned under the Administrative Procedure Code. S.: Sibi, 2015.

3. Buchkova, V. Claim Proceedings for damages from illegal administrative activity. S.: BAS, 2020

4. Buchkova, V. The New Moments in the Administrative Penal Liability under the Administrative Violations and Sanctions Act. - Administrative Justice Journal, 4, 2021.

5. Buchkova, V. The Normative Administrative Act. A.: Ekobelan, 2005.

6. Valkadinova V, Goranova I, Ilkova R, and Mitreva P. Administrative Penal Law. A Handbook. 2015, available at http://vssold.justice.bg/bg/e-guide/Topic04_AdminLaw.pdf.

7. Dimitrov, D. Administrative Law. General Part. Eighth edition. S.: Siela. 2006

8. Iliev, I. Administrative Law. S.: Publishing House „Zhazhda” 1995.

9. Lazarov, K. Administrative Law. S.: Feneia, 2009.

10. Saharov, K. Analysis of Changes and Amendments in Legal Regulations concerning Admin-istrative Penalty of Legal Persons and Merchants-Natural Persons. - Pravna Missal, 2007, 2, p. 63 - 76

11. Sivkov, T. The Administrative Penalty. Substantive and Procedural Issues. S.: Sofi-R, 1998.

12. Stoev, S. Scientific and Practical Commentary to the Administrative Violations and Sanctions Act. S .: Nauka i izkustvo, 1975.

13. Stoinov, Al. Criminal Law. General part. S.: Siela, 2013.

\footnotetext{
${ }^{1}$ Legislative changes in the institutes of administrative punishment should not be related to the introduction of legal possibilities for termination of proceedings despite the existence of committed administrative violations, as this should not be the goal of the legislator. Buchkova, V. The New Moments in the Administrative Penal Liability under the AVSA. - Administrative Justice Journal, 4, 2021.
} 